\title{
Studies on the Catabolism of $N^{\mathrm{G}}-$ Methylarginine, $N^{\mathrm{G}}, N^{\prime \mathrm{G}}-$ Dimethylarginine and $N^{G}, N^{G}$-Dimethylarginine in the Rabbit
}

\author{
By JOHN R. MCDERMOTT \\ M.R.C. Demyelinating Diseases Unit, Newcastle General Hospital, Westgate Road, \\ Newcastle upon Tyne NE4 6BE, U.K.
}

(Received 11 August 1975)

\begin{abstract}
1. The routes of elimination of $N^{\mathrm{G}}$-methylarginine, $N^{\mathrm{G}}, N^{\mathbf{G}}$-dimethylarginine and $N^{\mathbf{G}}, N^{\mathbf{G}}$-dimethylarginine were investigated in the rabbit. 2. Analyses showed low plasma concentrations of these amino acids (around $1 \mathrm{nmol} / \mathrm{ml}$ ) and ratios similar to those found in tissue proteins. The concentrations of these amino acids in extracts of brain, kidney, liver and spleen were similar except that liver had a lower concentration of $N^{\mathrm{G}}$-methylarginine and $N^{\mathbf{G}}, N^{\mathrm{G}}$-dimethylarginine. Cerebrospinal fluid contained traces of each amino acid. 3. The urinary excretion of $N^{\mathbf{G}}, N^{\prime \mathbf{G}}$ dimethylarginine was $\mathbf{3 0}$ times greater than that of either $N^{\mathbf{G}}$-methylarginine or $N^{\mathbf{G}}, N^{\mathbf{G}}$-dimethylarginine. The recoveries of intravenously injected amino acids in the urine were $0.14 \%$ ( $N^{G}$-methylarginine), $5.1 \%\left(N^{G}, N^{G}\right.$-dimethylarginine $)$ and $66 \%\left(N^{G}, N^{\prime G}\right.$-dimethylarginine $)$. Clearly $N^{\mathbf{G}}$-methylarginine and $N^{\mathbf{G}}, N^{\mathbf{G}}$-dimethylarginine are catabolized in some way, whereas $N^{\mathbf{G}}, N^{\mathbf{G}}$-dimethylarginine is largely excreted. 4. Intravenous injection of $N^{\mathrm{G}}$-methyl$\left[1{ }^{14} \mathrm{C}\right]$-arginine gave a variety of labelled products in the urine, among which were probably glutamic acid, ornithine and proline. $N^{\mathrm{G}}$-methyl[1-14 $\left.\mathrm{C}\right]$ arginine was recovered in $0.51 \%$ yield whereas $33 \%$ of the total radioactivity was recovered after 8 days. 5. Assays of tissue homogenates in vitro showed arginase-like activity with methylarginine and $N^{\mathbf{G}}$-methylarginine-glycine amidinotransferase-like activity, notably in the kidneys. Brain contains some $N^{\mathbf{G}}$-methyl-arginine-glycine amidinotransferase activity but does not appear to degrade $N^{\mathbf{G}}, N^{\prime \mathbf{G}}$-dimethylarginine or $N^{\mathbf{G}}, N^{\mathrm{G}}$-dimethylarginine.
\end{abstract}

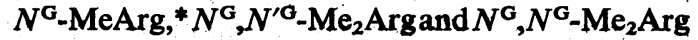
occur in several proteins, among which are myelin basic protein (Baldwin \& Carnegie, 1971) and histones (Paik \& Kim, 1970). An enzyme responsible for the methylation of arginine residues in proteins has been partially characterized (Paik \& Kim, 1968; Miyake \& Kakimoto, 1973). Appreciable quantities of $N^{\mathrm{G}}, N^{\prime \mathrm{G}}-\mathrm{Me}_{2} \mathrm{Arg}$ and $N^{\mathrm{G}}, N^{\mathrm{G}}-\mathrm{Me}_{2} \mathrm{Arg}$ are present in human urine (Kakimoto \& Akazawa, 1970).

Our interest in methylated arginines stemmed from the possibility that their concentration in body fluids may be an indicator of breakdown of myelin basic protein, which contains both $N^{G}$. MeArg and $N^{\mathrm{C}}, N^{\prime} \mathrm{G}-\mathrm{Me}_{2} \mathrm{Arg}$ and thus may be of value in studying demyelinating conditions in both man and experimental animals. The total protein of human white matter contains mainly $N^{\mathrm{G}}$-MeArg and $N^{\mathrm{G}}, N^{\prime G}-\mathrm{Me}_{2} \mathrm{Arg}$ by virtue of its high content of

* Abbreviations: $\quad N^{\mathrm{G}}$-MeArg, $\quad N^{\mathrm{G}}$-methylarginine; $N^{\mathrm{G}}, N^{\prime \mathbf{G}}-\mathrm{Me}_{2} \mathrm{Arg}, \quad N^{\mathrm{G}}, N^{\prime \mathrm{G}_{-}}$-dimethylarginine; $\quad N^{\mathrm{G}}, N^{\mathrm{G}}$ $\mathrm{Me}_{2} \mathrm{Arg}, N^{\mathrm{G}}, N^{\mathrm{G}}$-dimethylarginine. The superscript $\mathrm{G}$ refers to the guanidine moiety as follows:

$$
\begin{gathered}
\mathrm{H}_{2} \mathrm{~N}^{\mathrm{G}}-\mathrm{C}-\mathrm{NHCH}_{2} \mathrm{CH}_{2} \mathrm{CH}_{2} \mathrm{CH}\left(\mathrm{NH}_{2}\right) \mathrm{CO}_{2} \mathrm{H} \\
\mathrm{NH}^{\prime G}
\end{gathered}
$$

myelin basic protein, whereas protein from grey matter is considerably richer in $N^{\mathrm{G}}, N^{\mathrm{G}}-\mathrm{Me}_{2} \mathrm{Arg}$ (Kakimoto et al., 1975). This offers a potential means of differentiation in investigations of the pathological breakdown of brain tissue by analysis of the methylarginine degradation products. No studies have yet been reported on the metabolism of $N^{\mathrm{G}}$-methylarginines and so the route of elimination of these amino acids was investigated.

\section{Experimental}

\section{Synthesis of $N^{G}$-methylated arginines}

$N^{\mathbf{G}}-\mathrm{MeArg}, N^{\mathbf{G}}, N^{\mathbf{G}}-\mathrm{Me}_{2} \mathrm{Arg}$ and $N^{\mathbf{G}}, N^{\mathbf{G}}-\mathrm{Me}_{2} \mathrm{Arg}$ were synthesized by coupling 1,2-dimethylpseudourea, 1,2,3-trimethylpseudourea or 1,2,2-trimethylpseudourea respectively with the copper complex of ornithine in alkaline solution (Kakimoto \& Akazawa; 1970; Nakajima et al., 1971). The products were purified by ion-exchange chromatography, crystallized as their $4,4^{\prime}$-hydroxyazobenzene sulphonates and recrystallized twice from water. The melting points agreed with the published values (Kakimoto \& Akazawa, 1970; Nakajima et al., 1971). The purity of the product was assessed by methylarginine 
analysis on the column $(10 \mathrm{~cm} \times 0.9 \mathrm{~cm})$ described below. In all three cases, more than $95 \%$ of the ninhydrin-positive material was associated with a single peak. Ammonia, ornithine and, in the case of $N^{\mathbf{G}}$-MeArg, arginine were identified as minor impurities.

\section{Determination of $N^{G}$-methylated arginines}

A modification of the procedure of Kakimoto \& Akazawa (1970) was used. Before analysis, the aliphatic basic amino acid fraction was isolated from the sample by chromatography on a column $(4 \mathrm{~cm} \times 0.9 \mathrm{~cm})$ of Dowex-50 (X8; $\mathrm{H}^{+}$form). Elution with water $(20 \mathrm{ml})$ and $3 \mathrm{M}$-pyridine $(60 \mathrm{ml}$; adjusted to pH9.6 with $N$-ethylmorpholine) removed acidic, neutral and imidazole-containing amino acids and peptides. The basic fraction was eluted with $3 \mathrm{M}-\mathrm{NH}_{3}$ $(20 \mathrm{ml})$. Anserine, carnosine and homocarnosine were removed by this procedure.

It is difficult to determine $N^{\mathbf{G}}-\mathrm{MeArg}$ in the presence of high concentrations of arginine, owing to overlapping of the peaks. Accordingly, the basic sample was digested with 25 units of arginase [Sigma (London) Ltd., Kingston-upon-Thames, Surrey, U.K.] at $37^{\circ} \mathrm{C}$ for $24 \mathrm{~h}$ in sodium borate buffer (pH9.5) containing $\mathrm{Mn}^{2+}(5 \mathrm{mM})$ as suggested by Nakajima et al. (1971). Under the same conditions the methylated arginines are not affected.

The analysis was carried out on a column $(10 \mathrm{~cm} \times 0.9 \mathrm{~cm})$ of $\mathrm{M} 72$ resin (Beckman Instruments, Munich, Germany) by using $0.2 \mathrm{M}$-sodium citrate buffer, pH3.28, containing $0.5 \mathrm{M}-\mathrm{NaCl}$, at a flow rate of $35 \mathrm{ml} / \mathrm{h}$ at $50^{\circ} \mathrm{C}$ in a Locarte MK5 amino acid analyser. Elution times were: $N^{\mathrm{G}}$-MeArg, $184 \mathrm{~min} ; N^{\mathrm{G}}, N^{\prime \mathrm{G}}-\mathrm{Me}_{2} \mathrm{Arg}, 145 \mathrm{~min} ; N^{\mathrm{G}}, N^{\mathrm{G}}-\mathrm{Me}_{2} \mathrm{Arg}$, $135 \mathrm{~min}$; Arginine, 199 min.

\section{Preparation of samples from tissues and body fluids}

Adult New Zealand albino rabbits $(3-4 \mathrm{~kg})$ of either sex were used. Urine samples were collected over a $24 \mathrm{~h}$ period in a flask containing $0.5 \mathrm{ml}$ of octanoic acid. Cerebrospinal fluid $(0.8-1 \mathrm{ml})$ and blood $(20 \mathrm{ml}$ by cardiac puncture) were removed under ether anaesthesia and the animal was then killed by exsanguination. The whole brain, kidneys, spleen and liver were removed rapidly and immediately homogenized in ice-cold $5 \%(w / v)$ trichloroacetic acid $(5 \mathrm{ml} / \mathrm{g}$ of tissue), in a Waring Blendor at low speed. The suspension was centrifuged at $5000 \mathrm{~g}$ for $30 \mathrm{~min}$ and the supernatant liquid washed with $3 \times 2 \mathrm{vol}$. of diethyl ether in a separating funnel. The aqueous phase was applied to the ion-exchange column described above to isolate the aliphatic basic fraction.

Before application to the ion-exchange column, urine $(20 \mathrm{ml})$ was acidified to $\mathrm{pH} 2$ with $\mathrm{HCl}$ at $4^{\circ} \mathrm{C}$ and filtered; cerebrospinal fluid $(0.8-1 \mathrm{ml})$ was deproteinized with $5 \mathrm{mg}$ of sulphosalicylic acid at $4^{\circ} \mathrm{C}$, and plasma was separated from the blood sample, deproteinized with sulphosalicylic acid and diluted with an equal volume of water.

\section{Synthesis of $\mathrm{N}^{\mathrm{G}}-\mathrm{Me}\left[1-{ }^{14} \mathrm{C}\right] \mathrm{Arg}$}

$\left[1-{ }^{14} \mathrm{C}\right]$ Ornithine monohydrochloride $(45 \mu \mathrm{mol}$; $2.5 \mu \mathrm{Ci}$; The Radiochemical Centre, Amersham, Bucks., U.K.) was converted into $N^{\mathbf{G}}-\mathrm{Me}\left[1-{ }^{14} \mathrm{C}\right]-$ Arg by the method of Kakimoto \& Akazawa (1970). An aqueous solution of the product was applied to a column $(26 \mathrm{~cm} \times 0.9 \mathrm{~cm})$ of Dowex-50 $\left(\mathrm{X8} ; \mathrm{NH}_{4}{ }^{+}\right.$ form). The column was eluted with $0.3 \mathrm{M}-\mathrm{NH}_{3}$ $(20 \mathrm{ml})$ followed by a linear gradient of $0.3-3 \mathrm{M}-\mathrm{NH}_{3}$ $(50 \mathrm{ml}$ total). Two radioactive fractions were found at $V_{\mathrm{c}}=10-17.5 \mathrm{ml}(\mathrm{A})$ and $47.5-65 \mathrm{ml}$ (B). Portions of fractions (A) and (B) were evaporated, dansylated (Gray, 1972) and the product was identified by t.l.c. on polyamide sheets (Woods \& Wang, 1967). Fraction (A) was identified as ornithine and (B) as $N^{\mathrm{G}}$-MeArg. Fraction (B) gave a single ninhydrinpositive radioactive peak on amino acid analysis by using a stream divider. The yield of $N^{\mathrm{G}}-\mathrm{Me}\left[1-{ }^{14} \mathrm{C}\right] \mathrm{Arg}$ was $6.5 \mu \mathrm{mol}(14 \%)$ and $1.8 \mu \mathrm{Ci}$.

\section{Injection of $N^{G}$-methylarginines}

The amount of each methylarginine for accurate estimation of urinary excretion was found from preliminary experiments. A solution in $0.9 \% \mathrm{NaCl}$ $(0.5 \mathrm{ml})$ of $N^{\mathrm{G}}-\mathrm{Me}\left[1-{ }^{14} \mathrm{C}\right] \mathrm{Arg}(0.9 \mu \mathrm{Ci}), N^{\mathrm{G}}-\mathrm{MeArg}$ $(50 \mu \mathrm{mol}), N^{\mathrm{G}}, N^{\prime \mathbf{G}}-\mathrm{Me}_{2} \mathrm{Arg}(4 \mu \mathrm{mol})$ or $N^{\mathrm{G}}, N^{\mathrm{G}}$. $\mathrm{Me}_{2} \mathrm{Arg}(20 \mu \mathrm{mol})$ was injected into a peripheral ear vein of a rabbit. Animals were maintained on standard pellets and water ad libitum and kept in metabolism cages during the study, and $24 \mathrm{~h}$ urine samples were collected for 6 days before and 6 days after the injection. The non-radioactive urine samples were treated as described above.

\section{Determination of radioactivity}

Untreated urine or column effluent $(0.5 \mathrm{ml})$ was diluted to $1.5 \mathrm{ml}$ with water and counted for radioactivity in $10 \mathrm{ml}$ of scintillant (Bray, 1960) at $4^{\circ} \mathrm{C}$ in a Packard Tri-Carb model 3320 scintillation counter. Quench corrections were determined by the internal-standard method, by using $25 \mu \mathrm{l}$ of an aqueous solution of ${ }^{14} \mathrm{C}$-labelled protein hydrolysate (The Radiochemical Centre, Amersham, Bucks., U.K.). Counting efficiency was between $20 \%$ and $46 \%$.

\section{Ion-exchange chromatography of radioactive urine}

The combined radioactive urine $(0-48 \mathrm{~h}, 163 \mathrm{ml})$ was adjusted to $\mathrm{pH} 2$ with $1 \mathrm{M}-\mathrm{HCl}$, filtered and 
passed down a column $(5 \mathrm{~cm} \times 2.5 \mathrm{~cm})$ of Dowex-50 (X8). The column was eluted with water $(100 \mathrm{ml})$ and $3 \mathrm{M}-\mathrm{NH}_{3}(150 \mathrm{ml})$. The radioactivity of the effluents was determined. The basic fraction containing the amino acids was evaporated, a sample dissolved in $0.2 \mathrm{M}$-sodium citrate buffer (pH2.2) and applied to the amino acid analyser column. Neutral and acidic amino acids were determined on a $25 \mathrm{~cm} \times 0.9 \mathrm{~cm}$ column of Beckman $\mathrm{M} 72$ resin by using $0.2 \mathrm{M}$ sodium citrate buffers of $\mathrm{pH} 3.28$ and 4.25 at a flow rate of $35 \mathrm{ml} / \mathrm{h}$ at $50^{\circ} \mathrm{C}$. The basic amino acids were determined on the $10 \mathrm{~cm}$ column as described above.

\section{$N^{\mathrm{G}}$-MeArg degradation by tissue homogenates}

Tissue was removed from the rabbit as quickly as possible after death and homogenized in a glass/ Teflon homogenizer in water $(10 \mathrm{ml} / \mathrm{g})$ containing $0.05 \%$ (w/v) mercaptoethanol and $0.5 \%$ (w/v) Triton X-100. For glycine amidinotransferase activity, $50 \mu \mathrm{l}$ of homogenate were incubated with $50 \mu \mathrm{l}$ of a solution of $N^{\mathrm{G}}$-MeArg $(6.6 \mathrm{mM})$ and glycine $(6.6 \mathrm{mM})$ in $0.1 \mathrm{M}$-sodium phosphate buffer, $\mathrm{pH} 7.2$, at $37^{\circ} \mathrm{C}$ for $2 \mathrm{~h}$, or for arginase activity with $50 \mu \mathrm{l}$ of $N^{\mathrm{G}}$-MeArg $(6.6 \mathrm{~mm})$ in $0.05 \mathrm{M}$-sodium borate buffer (pH9.5) containing $\mathrm{MnSO}_{4}(25 \mathrm{~mm})$ at $37^{\circ} \mathrm{C}$ for $2 \mathrm{~h}$
(Greenberg, 1960). In each case the reaction was stopped with $200 \mu \mathrm{l}$ of aq. $10 \%$ (w/v) trichloroacetic acid. A sample $(200 \mu \mathrm{l})$ was diluted to $1 \mathrm{ml}$ with $0.2 \mathrm{M}$-sodium citrate buffer, $\mathrm{pH} 2.2$, and applied directly to the $10 \mathrm{~cm}$ column of the amino acid analyser, for determination of $N^{\mathbf{G}}$-MeArg and arginine as described above.

\section{Results}

The concentrations of $N^{\mathbf{G}}-\mathrm{MeArg}, N^{\mathbf{G}}, N^{\mathbf{G}}-\mathrm{Me}_{2} \mathrm{Arg}$ and $N^{\mathbf{G}}, N^{\mathbf{G}}-\mathrm{Me}_{2}$ Arg in normal urine, plasma, cerebrospinal fluid and extracts of the various tissues are shown in Table 1. Standard amounts of $N^{\mathbf{G}}$-MeArg, $N^{\mathrm{G}}, N^{\prime \mathrm{G}}-\mathrm{Me}_{2} \mathrm{Arg}$ and $N^{\mathrm{G}}, N^{\mathrm{G}}-\mathrm{Me}_{2} \mathrm{Arg}$ taken through the isolation procedure were recovered in $88-95 \%$ yield. The limit of detection of the methylated arginines is of the order $0.5 \mathrm{nmol} ; 2 \mathrm{nmol}$ of each amino acid can be determined with an accuracy of $\pm 20 \%$.

The amounts of $N^{\mathrm{G}}$-MeArg, $N^{\mathbf{G}}, N^{\prime \mathbf{G}_{-}} \mathrm{Me}_{2} \mathrm{Arg}$ and $N^{\mathbf{G}}, N^{\mathbf{G}}-\mathrm{Me}_{2} \mathrm{Arg}$ in $24 \mathrm{~h}$ urine samples before and after intravenous injection of saline solutions of the amino acids are shown in Table 2 . The increase in output after injection was determined by subtracting the mean $24 \mathrm{~h}$ value before injection

Table 1. Concentration of methylarginines in body fluids

Samples were prepared and analysed as described in the Experimental section. The results are means \pm S.E.M. of three determinations. The cerebrospinal fluid samples were not large enough for accurate determinations.

Concentration (nmol/ml or $\mathrm{nmol} / \mathrm{g}$ of wet tissue)

\begin{tabular}{|c|c|c|c|c|}
\hline Fluid & $N^{\mathrm{G}}$-MeArg & $N^{\mathrm{G}}, N^{\mathrm{G}}-\mathrm{Me}_{2} \mathrm{Arg}$ & $N^{\mathrm{G}}, N^{\prime \mathrm{G}}-\mathrm{Me}_{2} \mathrm{Arg}$ & Arg \\
\hline $\begin{array}{l}\text { Urine } \\
\text { Plasma } \\
\text { Cerebrospinal fluid }\end{array}$ & $\begin{array}{c}0.1 \pm 0.05 \\
0.4 \pm 0.2 \\
0-0.5\end{array}$ & $\begin{array}{c}0.1 \pm 0.01 \\
1.6 \pm 0.5 \\
0-0.5\end{array}$ & $\begin{array}{c}3.1 \pm 0.2 \\
0.3 \pm 0.1 \\
0-0.5\end{array}$ & $\begin{array}{r}10 \pm 2 \\
246 \pm 23 \\
37 \pm 3\end{array}$ \\
\hline \multicolumn{5}{|l|}{ Tissue extracts } \\
\hline $\begin{array}{l}\text { Brain } \\
\text { Liver } \\
\text { Kidney } \\
\text { Spleen }\end{array}$ & $\begin{array}{c}1.4 \pm 0.4 \\
<0.2 \\
0.6 \pm 0.1 \\
0.7 \pm 0.3\end{array}$ & $\begin{array}{c}1.0 \pm 0.5 \\
0.27 \pm 0.07 \\
1.5 \pm 0.7 \\
1.8 \pm 0.1\end{array}$ & $\begin{array}{l}1.2 \pm 0.1 \\
0.7 \pm 0.1 \\
1.8 \pm 0.6 \\
0.3 \pm 0.1\end{array}$ & $\begin{array}{r}285 \pm 26 \\
54 \pm 12 \\
168 \pm 20 \\
192 \pm 17\end{array}$ \\
\hline
\end{tabular}

\section{Table 2. Effect of intravenous injections of methylarginines on their concentration in urine}

A solution of the amino acid ( $N^{\mathrm{G}}-\mathrm{MeArg}, 50 \mu \mathrm{mol} ; N^{\mathrm{G}}, N^{\prime \mathrm{G}}-\mathrm{Me}_{2} \mathrm{Arg}, 4 \mu \mathrm{mol}$; or $\left.N^{\mathrm{G}}, N^{\mathrm{G}}-\mathrm{Me}_{2} \mathrm{Arg}, 20 \mu \mathrm{mol}\right)$ in $0.5 \mathrm{ml}$ of $0.9 \%$ $\mathrm{NaCl}$ was injected into the peripheral ear vein of the rabbit; $24 \mathrm{~h}$ urine samples were collected and analysed as described in the Experimental section. The recovery of each amino acid was calculated as: (sum of post-injection values) $-6 \times$ (mean pre-injection excretion value) and is expressed as the percentage of the amount injected.

\begin{tabular}{|c|c|c|c|c|c|c|c|c|}
\hline & \multirow{2}{*}{$\begin{array}{l}\text { Mean ( } \pm \text { S.E.M.) } 24 \mathrm{~h} \text { excretion } \\
\text { over } 6 \text { days before injection } \\
\text { (nmol) }\end{array}$} & \multicolumn{6}{|c|}{ Excretion after injection (nmol) } & \multirow[b]{2}{*}{$\begin{array}{c}\text { Recovery } \\
(\%)\end{array}$} \\
\hline & & $\ldots 1$ & 2 & 3 & 4 & 5 & 6 & \\
\hline $\begin{array}{l}N^{\mathrm{G}}-\mathrm{MeArg} \\
N^{\mathrm{G}}, N^{\prime \mathrm{G}}-\mathrm{Me}_{2} \mathrm{Arg} \\
N^{\mathrm{G}}, N^{\mathrm{G}}-\mathrm{Me}_{2} \text { Arg }\end{array}$ & $\begin{array}{r}16 \pm 3 \\
601 \pm 140 \\
20 \pm \quad 2\end{array}$ & $\begin{array}{r}70 \\
948 \\
947\end{array}$ & $\begin{array}{r}10 \\
1860 \\
17\end{array}$ & $\begin{array}{r}24 \\
1692 \\
28\end{array}$ & $\begin{array}{r}18 \\
801 \\
34\end{array}$ & $\begin{array}{r}16 \\
480 \\
38\end{array}$ & $\begin{array}{r}16 \\
468 \\
30\end{array}$ & $\begin{array}{l}0.14 \\
66 \\
5.1\end{array}$ \\
\hline
\end{tabular}

Vol. 154 
from the $24 \mathrm{~h}$ amounts of amino acid determined in the 6 days after injection. Virtually none of the injected $N^{\mathbf{G}}$-MeArg was recovered in the urine.

The percentage of the total radioactivity in $24 \mathrm{~h}$ urine samples after injection of $N^{\mathbf{G}}-\mathrm{Me}\left[1-{ }^{14} \mathrm{C}\right] \mathrm{Arg}$ is shown in Table 3. After 8 days, $33 \%$ of the label had been recovered in the urine. The aqueous effluent (not amino acids) from the Dowex-50 (X8) purification of the combined $0-48 \mathrm{~h}$ urine contained $19 \%$ of the recovered radioactivity, and $78 \%$ was present in the basic fraction. The radioactivity associated with the various amino acids is shown in Fig. 1.

The results of the assay for $N^{\mathrm{G}}$-methylarginineglycine amidinotransferase activity in tissue homogenates are shown in Table 4. Of the four tissues

Table 3. Radioactivity in rabbit urine after intravenous injection of $\mathrm{N}^{\mathrm{G}}-\mathrm{Me}\left[1-{ }^{14} \mathrm{C}\right] \mathrm{Arg}$

$N^{\mathrm{G}}-\mathrm{Me}\left[1-{ }^{14} \mathrm{C}\right] \mathrm{Arg}(0.9 \mu \mathrm{Ci})$ in $0.5 \mathrm{ml}$ of $0.9 \% \mathrm{NaCl}$ was injected into the peripheral ear vein of a rabbit; $24 \mathrm{~h}$ urine samples were collected and radioactivity was determined. For further details, see the Experimental section.

\begin{tabular}{|c|c|c|c|c|c|c|c|c|}
\hline Day & 1 & 2 & 3 & 4 & 5 & 6 & 7 & 8 \\
\hline adioactivity in urine ( $\%$ of total injected) & 10.7 & 19 & 0.8 & 0.5 & 0.5 & 0.6 & 0.5 & 0.4 \\
\hline
\end{tabular}

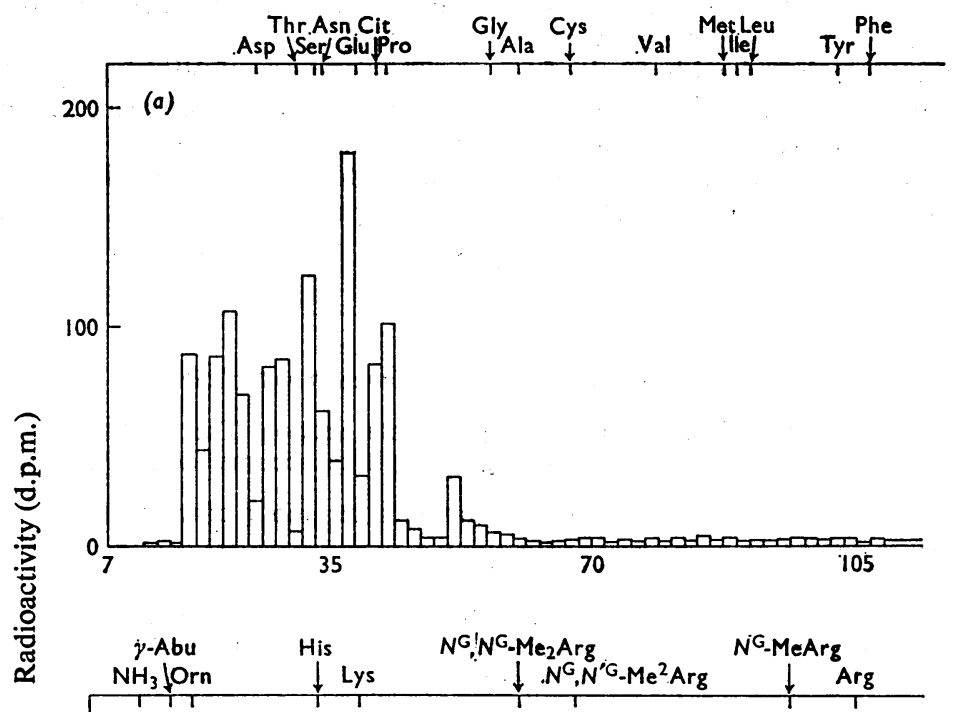

(b)

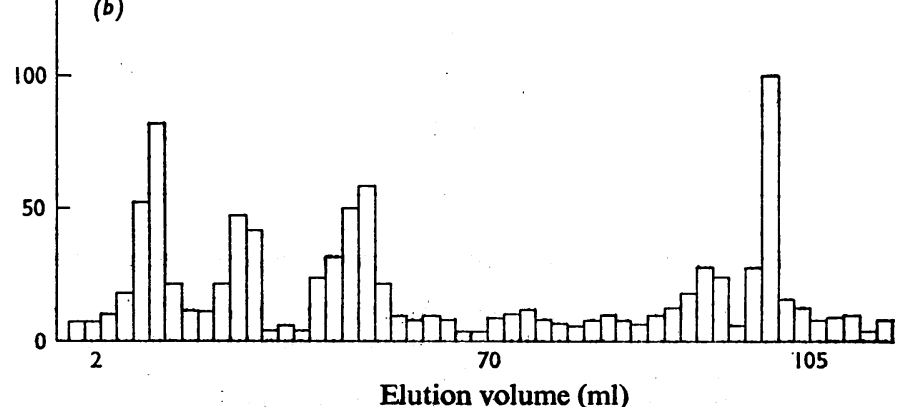

Fig. 1. Distribution of radioactivity in the (a) neutral and acid amino acids; and (b) basic amino acids of rabbit urine after injection of $\mathrm{N}^{\mathrm{G}}-\mathrm{Me}\left[1-{ }^{14} \mathrm{C}\right] \mathrm{Arg}$

Urine $(0-48 \mathrm{~h})$ was collected from a rabbit injected intravenously with $N^{\mathrm{G}}-\mathrm{Me}\left[1-{ }^{14} \mathrm{C}\right] \mathrm{Arg}$. The combined amino acids were isolated from the urine and separate samples were used for the analysis of $(a)$ neutral and acidic and $(b)$ basic amino acids. For details see the Experimental section and Table 3. The samples analysed in $(a)$ and $(b)$ correspond to $1 / 250$ th and $1 / 70$ th respectively of the total amino acid fraction. Cit, citrulline; $\gamma$-Abu, $\gamma$-aminobutyric acid. 
Table 4. Degradation of $N^{\mathrm{G}}$-methylarginine and arginine by rabbit tissue homogenates

Tissue homogenates were assayed under the conditions described for arginase or glycine amidinotransferase activity with methylarginine or arginine.

Enzyme activity ( $\mu \mathrm{mol}$ of substrate degraded/2h per $\mathrm{g}$ of tissue)

\begin{tabular}{|c|c|c|c|c|c|}
\hline \multirow[b]{2}{*}{ Tissue } & \multirow[b]{2}{*}{ Substrate } & \multicolumn{2}{|c|}{ Arginase } & \multicolumn{2}{|c|}{ Glycine amidinotransferase } \\
\hline & & $\ldots \quad N^{\mathbf{G}}-\mathrm{MeArg}$ & Arginine & $N^{\mathbf{G}}$-MeArg & Arginine \\
\hline Kidney & & $15,16,7.8,9.2$ & 6.0 & $6.4,4.8$ & 24 \\
\hline Brain & & $<1.0$ & - & $3.3,5.2,2.3$ & 1.0 \\
\hline Liver & & $1.8,2.5,2.3$ & 48 & $2.4,2.6$ & 33 \\
\hline Spleen & & - & - & $<1.0$ & - \\
\hline
\end{tabular}

assayed, kidney and brain had the highest activities. For comparison, under the same conditions arginine was catabolized 24 times faster by kidney than by brain homogenate. Catabolism of $N^{\mathbf{G}}, N^{\mathbf{G}}-\mathrm{Me}_{2} \mathrm{Arg}$ and $N^{\mathbf{G}}, N^{\prime \mathbf{G}}-\mathrm{Me}_{2} \mathrm{Arg}$ by brain homogenate was not detected under these conditions.

Arginase-like activity in brain, kidney and liver homogenates was assayed by using $N^{\mathbf{G}}-\mathrm{MeArg}$ as the substrate. Kidney again had the highest activity (Table 4). Arginase activity is normally highest in the liver, and an assay using arginine in place of $N^{\mathbf{G}}$ MeArg showed that this was indeed the case in the rabbit homogenates. Since the kidney homogenate had the highest activity in both arginase-like and amidinotransferase-like assays it was examined further. In the absence of added glycine or $\mathrm{Mn}^{2+}$, no measurable degradation of $N^{\mathbf{G}}-$ MeArg occurred in $0.1 \mathrm{M}$-Tris/HCl buffer at $\mathrm{pH} 6, \mathrm{pH7}$.2, $\mathrm{pH} 8.5$ and pH9.5 when substrate and tissue homogenate concentrations as before were used; and it is concluded that the decreases in methylarginine recorded (Table 4) are reliable indicators of arginaselike and amidinotransferase-like activity.

\section{Discussion}

Little attention has been paid to the metabolism of methyl-amino acids and, in particular, no information is available about the metabolic fate of methylarginines. The present work shows that the main fate of $N^{\mathbf{G}}$-MeArg in the rabbit is degradation and that the kidney may be the main site for this catabolism. The evidence suggests that $N^{\mathbf{G}}, N^{\mathbf{G}}-\mathrm{Me}_{2} \mathrm{Arg}$ is degraded to a lesser extent and that most of the $N^{\mathbf{G}}, N^{\prime \mathbf{G}}$. $\mathrm{Me}_{2} \mathrm{Arg}$ is excreted in the urine.

The occurrence of methylated arginine, lysine and histidine residues in certain proteins is well established (Paik \& Kim, 1971). The presence of $\varepsilon-N$-mono-, diand tri-methyl-lysine, $N^{\mathbf{G}}, N^{\mathbf{G}}-\mathrm{Me}_{2} \mathrm{Arg}$ and $N^{\mathbf{G}}, N^{\prime \mathbf{G}}$ $\mathrm{Me}_{2} \mathrm{Arg}$ in urine has been demonstrated (Kakimoto \& Akazawa, 1970) and it is probable that these methylated amino acids arise mainly, if not entirely, from degradation of the corresponding methylated protein. It has been tacitly assumed that the methylated amino acids are not re-used for protein synthesis. The appearance of relatively large amounts of these $\omega$-methyl-amino acids in urine argues against their being catabolized to any great extent, since they are initially present in only trace amounts in proteins. For example, it has been shown that rat brain protein contains $1.1 \mu \mathrm{mol}$ of $N^{\mathbf{G}}, N^{\mathbf{G}}-\mathrm{Me}_{2} \mathrm{Arg}$ and $0.31 \mu \mathrm{mol}$ of $N^{G}, N^{\prime G}-M_{2} \mathrm{Arg} / \mathrm{g}$ and that these amino acids also occur in similar amounts in the total protein of liver, spleen, kidney, intestine and lung (Nakajima et al., 1971). The concentration of $N^{\mathbf{G}}, N^{\mathbf{G}}-\mathrm{Me}_{2} \mathrm{Arg}$ in plasma is around four or five times higher than that of $N^{\mathbf{G}}-\mathrm{MeArg}$ and $N^{\mathbf{G}}, N^{\prime \mathbf{G}}$ $\mathbf{M e}_{2} \mathrm{Arg}$, reflecting the ratios found in tissue proteins (Nakajima et al., 1971), and cerebrospinal fluid contains traces of each amino acid. By contrast normal urinecontains 30 times more $N^{\mathbf{G}}, N^{\prime \mathbf{G}}-\mathrm{Me}_{2} \mathrm{Arg}$ than $N^{\mathrm{G}}$-MeArg and $N^{\mathrm{G}}, N^{\mathrm{G}}-\mathrm{Me}_{2} \mathrm{Arg}$. This alone points to some catabolic pathway for $N^{G}-$ MeArg and $N^{\mathbf{G}}, N^{\mathbf{G}}-\mathrm{Me}_{2} \mathrm{Arg}$ in the rabbit.

The difference in the recoveries in urine of intravenously injected $N^{\mathbf{G}}$-MeArg $(0.14 \%)$ and $N^{G}, N^{G}$ $\mathrm{Me}_{2} \mathrm{Arg}\left(5.1 \%\right.$ ) compared with $N^{\mathbf{G}}, N^{\prime \mathbf{G}}-\mathrm{Me}_{2} \mathrm{Arg}$ $(66 \%)$ supports this suggestion. It is noteworthy that human urine contains relatively large concentrations of both $N^{\mathbf{G}}, N^{\prime \mathbf{G}}-\mathrm{Me}_{2} \mathrm{Arg}$ and $N^{\mathbf{G}}, N^{\mathbf{G}}$ $\mathrm{Me}_{2} \mathrm{Arg}$ (20-60 nmol/g of creatinine; Kakimoto \& Akazawa, 1970) but little $N^{\mathbf{G}}$-MeArg (1-2nmol/g of creatinine; J. R. McDermott, unpublished work).

Fig. 1 shows that after injection of $N^{\mathrm{G}}-\mathrm{Me}\left[1-^{14} \mathrm{C}\right]-$ Arg much of the radioactivity in the urine is associated with the neutral and acidic amino acids. Under the elution conditions used it is difficult to make unequivocal assignments to the radioactive peaks, but it appears that the glutamic acid and proline regions are labelled. Among the radioactive basic amino acids are ornithine and $N^{\mathrm{G}}$-MeArg (Fig. $1 b$ ), the latter representing $0.51 \%$ of the radioactivity of the injected $N^{\mathrm{G}}-\mathrm{Me}\left[1-{ }^{14} \mathrm{C}\right] \mathrm{Arg}$. This provides good confirmation of the result obtained 
with the unlabelled amino acid. The metabolism of the $N^{\mathrm{G}}$-Me[1- $\left.{ }^{14} \mathrm{C}\right] \mathrm{Arg}$ not excreted $(67 \%$ of the total after 8 days) has not been investigated, nor has the neutral radioactive material eluted from the Dowex50 column during preparation of the amino acid fraction for analysis been characterized. The labelled amino acids in the urine thus represent only one aspect of the catabolism of $N^{\mathrm{G}}$-MeArg.

The mechanism by which $N^{\mathrm{G}}$-MeArg is catabolized in the rabbit is not known, but some speculation can be made from the above data. It is unlikely that a simple demethylation takes place analogous to the enzymic demethylation of $N^{\varepsilon}$-methyl-lysine and $N^{e}$-dimethyl-lysine (Kim et al., 1964), since no radioactivity was found corresponding to arginine. The appearance of radioactivity in the acidic and neutral amino acids can be explained by a prior degradation of $N^{\mathrm{G}}$-MeArg to ornithine, which is known to be a precursor for glutamic acid and proline (see, e.g. Benuck et al., 1972). Arginine is degraded to ornithine and urea by arginase (L-arginine amidinohydrolase, EC 3.5.3.1) in the liver, and to a lesser extent in brain and kidney. However, arginase from bovine liver does not degrade $N^{\mathbf{G}}$-MeArg (nor $N^{\mathbf{G}}, N^{\prime \mathbf{G}}-\mathrm{Me}_{2} \mathrm{Arg}$ and $N^{\mathbf{G}}, N^{\mathbf{G}}-\mathrm{Me}_{2} \mathrm{Arg}$ ) to any great extent under conditions giving the complete degradation of arginine (J. R. McDermott, unpublished work; Nakajima et al., 1971) and is therefore an unlikely route of catabolism. Under conditions favouring arginase activity (pH9.5 and $25 \mathrm{~mm}-\mathrm{Mn}^{2+}$ ) the rabbit liver homogenate did degrade $N^{\mathbf{G}}$-MeArg slowly. More surprising, the activity in the kidney homogenate was five times greater than in the liver. This is in direct contrast with arginase activity, which is higher in liver than kidney.

L-Arginine-glycine amidinotransferase (EC2.1.4.1) activity is also involved as an important degradative pathway for arginine and studies in vitro have shown that kidney is the major site for this enzyme in the rat (Van Pilsum et al., 1972). Glycine is the acceptor molecule, giving glycocyamine and ornithine. Brain is also the site of some amidinotransferase activity, where both glycine and $\gamma$-aminobutyric acid can act as acceptors (Sadasivudu \& Indira, 1974). The present preliminary results show that kidney, brain and liver homogenates are capable of using $N^{\mathbf{G}}$. MeArg in an amidinotransferase-like reaction with glycine. As with arginine amidino transfer, kidney has the highest activity and it is likely that $N^{\mathbf{G}}$. MeArg is also a substrate for the arginine enzyme. From the lack of demonstrable activity in the kidney homogenate over a range of $\mathrm{pH}$ when no $\mathrm{Mn}^{2+}$ or glycine is added, it seems that arginase-like and amidinotransferase-like reactions may be the main $N^{\mathbf{G}}$-MeArg degradation pathways. As a final proof, the identification and measurement of the products of arginase-like degradation of $N^{\mathbf{G}}$-MeArg (ornithine and $N$-methylurea) and amidino transfer-like reaction (ornithine and $N$-methylguanidinoacetic acid) in the assay in vitro and in urine will be necessary.

The use of $N^{\mathrm{G}}$-MeArg concentrations in urine as an indicator of breakdown of brain proteins is not possible because of this degradative pathway. Although $N^{\mathrm{G}}, N^{\prime \mathrm{G}}-\mathrm{Me}_{2} \mathrm{Arg}$ is largely excreted, it is present in urine in too great a concentration to allow small fluctuations to be detected. However, elevated concentrations of methylarginines are sometimes found in the cerebrospinal fluid of rabbits with nonspecific tissue destruction due to cerebral injury and with experimental allergic encephalomyelitis (J. R. McDermott, unpublished work).

I thank Dr. D. H. Adams for valuable advice and discussions, Mr. A. B. Keith for performing the animal experiments and Mrs. Jane Ingram for providing excellent technical assistance.

\section{References}

Baldwin, G. S. \& Carnegie, P. R. (1971) Science 171, 579-581

Benuck, M., Stern, F. \& Lajtha, A. (1972) J. Neurochem. 18, $1555-1567$

Bray, G. A. (1960) Anal. Biochem. 1, 279-285

Gray, W. R. (1972) Methods Enzymol. 35B, 121-138

Greenberg, D. M. (1960) Enzymes, 2nd edn., 4, 257-267

Kakimoto, Y. \& Akazawa, S. (1970) J. Biol. Chem. 245, 5751-5758

Kakimoto, Y., Matsuoka, Y. \& Konishi, H. (1975) J. Neurochem. 24, 893-902

Kim, S., Benoiton, L. \& Paik, W. K. (1964) J. Biol. Chem. 239, 3790-3796

Miyake, M. \& Kakimoto, Y. (1973) J. Neurochem. 20, 859-871

Nakajima, T., Matsuoka, Y. \& Kakimoto, Y. (1971) Biochim. Biophys. Acta 230, 212-222

Paik, W. K. \& Kim, S. (1968) J. Biol. Chem. 243, 2108-2114

Paik, W. K. \& Kim, S. (1970) J. Biol. Chem. 245, 88-92

Paik, W. K. \& Kim, S. (1971) Science 174, 114-119

Sadasivudu, B. \& Indira, H. R. (1974) Brain Res. 79, 326-329

Woods, K. R. \& Wang, K. T. (1967) Biochim. Biophys. Acta 133, 369-376

Van Pilsum, J. F., Stephens, G. C. \& Taylor, D. (1972) Biochem. J. 126, 325-345 